\title{
Factors associated with worse outcomes in patients with acute ST segment elevation myocardial infarction: experience in sex differences from the Croatian Branch of the ISACS-CT Registry
}

\author{
Filip Lončarić*, \\ Dora Fabijanović, \\ Nina Jakuš, \\ Petra Mjehović, \\ Dorja Sabljak, \\ Antonija Mišković, \\ Dominik Oroz, \\ Maja Čikeš, \\ Davor Miličić
}

University of Zagreb School of Medicine, University Hospital Centre Zagreb, Zagreb,

Croatia

RECEIVED:

September 1, 2017

ACCEPTED:

September 26, 2017

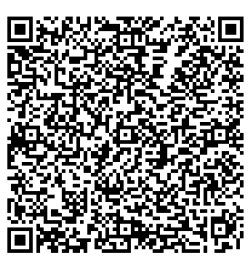

KEYWORDS: acute coronary syndrome, ISACS-CT, gender differences, ST segment elevation acute myocardial infarction.

CITATION: Cardiol Croat. 2017;12(9-10):392-393. | https://doi.org/10.15836/ccar2017.392

*ADDRESS FOR CORRESPONDENCE: Filip Lončarić, Klinički bolnički centar Zagreb, Kišpatićeva 12, HR-10000 Zagreb, Croatia. / Phone: +385-91-2220-480 / E-mail: Ioncaric.filip@gmail.com

ORCID: Filip Lončarić http://orcid.org/0000-0002-7865-1108 • Dora Fabijanović http://orcid.org/0000-0003-2633-3439 Nina Jakuš http://orcid.org/0000-0001-7304-1127 • Petra Mjehović http://orcid.org/0000-0003-4908-4674 Dorja Sabljak http://orcid.org/0000-0002-7785-5555 • Antonija Mišković http://orcid.org/0000-0002-8483-3856 Dominik Oroz http://orcid.org/0000-0002-9837-7214 • Maja Čikeš http://orcid.org/0000-0002-4772-5549 Davor Miličić http://orcid.org/0000-0001-9101-1570

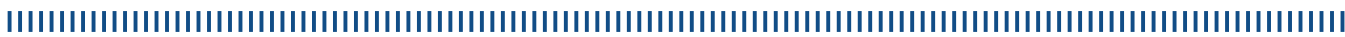

Background: Women have poorer outcomes in acute coronary syndrome (ACS) due to older age, comorbidities, atypical presentation and delay in admission. ${ }^{1}$ The aim is to consider gender differences in outcomes in the Croatian Branch of the ISACS-CT registry.

Methods: From January 2012 to February 2017, 1808 patients were enrolled in the Croatian branch of the registry, $46 \%(n=844)$ presenting with acute ST segment elevation acute myocardial infarction (STEMI), 35\% ( $\mathrm{n}=637$ ) with non-ST segment elevation myocardial infarction (NSTEMI) and 18\% ( $\mathrm{n}=327)$ with unstable angina. Sex ratio, male to female, was 2.2:1, the median age 65 (57-75) years. In-hospital mortality was defined as the primary outcome.

Results: There was no sex difference in type of ACS at admission. Women were significantly older, generally more burdened with comorbidities and arrived to the hospital with more delay from symptom onset (women vs. men: in the first $2 \mathrm{~h}-19 \%$ vs. 24\%, p=0.02; in the first $6 \mathrm{~h}-49 \%$ vs. 58\%, $\mathrm{p}<0.01$ ). In patients with STEMI, logistic analysis showed female sex (OR $=2.9, \mathrm{CI} 95 \%$ 1.1-8.1., $p=0.04)$, diabetes $(\mathrm{OR}=2.7)$, creatinine levels $(\mathrm{OR}=1.01)$ and time from onset to admission $(\mathrm{OR}=0.65)$, as independent factors associated with in-hospital mortality (Figure 1). Considering time from symptom onset to admission, worse outcomes in women were visible only in the 2-6 hour window (women vs. men: 15.3\% vs. $2.5 \%, p>0.01$ ) (Figure 2). There was no gender difference in undergoing percutaneous coronary intervention (PCI), but successful revascularization was less often achieved in women ( $92 \% \mathrm{vs.} 97 \%, \mathrm{p}<0.01)$. Moreover, female sex (OR = 4.7, CI 95\% 1.5-14.7, $\mathrm{p}=0.021)$, together with creatinine levels $(\mathrm{OR}=1.01)$ and GB 
IIB/IIIA administration ( $\mathrm{OR}=2.7)$, proved independently associated with in-hospital mortality in the PCI group, whereas this effect was not seen in the non-invasive treatment group.

Conclusion: Gender differences in patients presenting with STEMI are visible in the Croatian branch of the ISACS-CT registry. In this setting, female sex bears risk of worse outcome associated with delay in admission and invasive treatment.

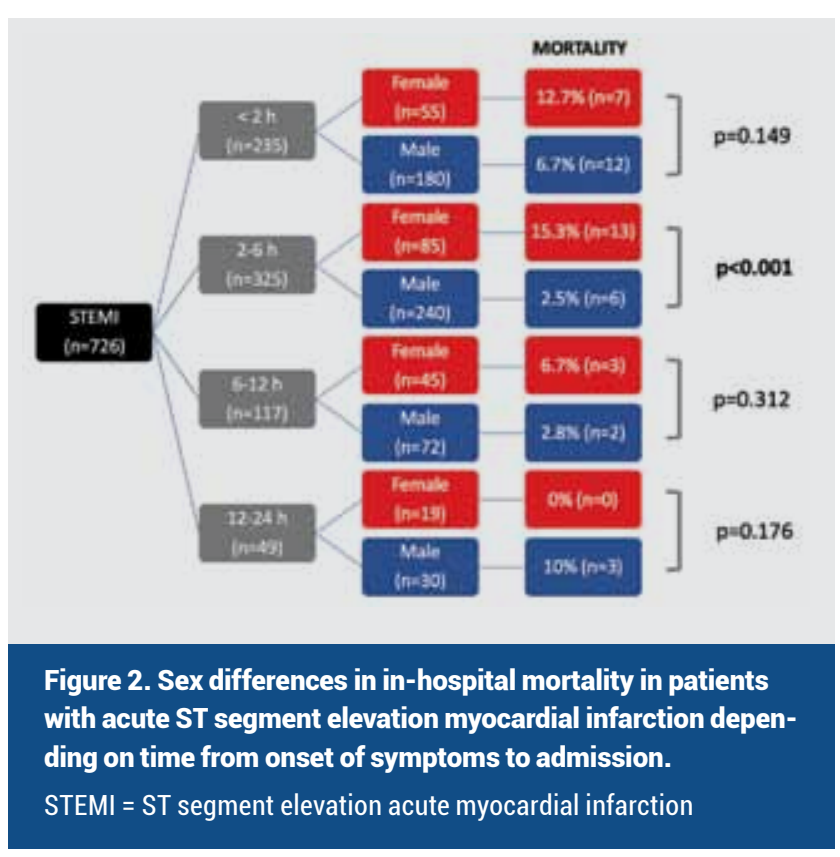

